\title{
Innovation trough Tradition in Family Business
}

\author{
Cinzia Vallone ${ }^{1} \&$ Barbara Iannone $^{2}$ \\ ${ }^{1}$ Assistant Professor of Accounting, University of Bicocca, Milan, Italy \\ ${ }^{2}$ Assistant Professor of Business Administration, University G. d'Annunzio, Chieti-Pescara, Italy \\ Correspondence: Cinzia Vallone, Assistant Professor of Accounting - University of Bicocca, Milan, Italy. E-mail: \\ cinzia.vallone@unimib.it
}

Received: November 23, 2019

Accepted: December 20, 2019

Online Published: December 29, 2019

doi:10.5539/ijbm.v15n1p157

URL: https://doi.org/10.5539/ijbm.v15n1p157

\begin{abstract}
This study attempts to explore the role of tradition in the development of innovations in the pasta sector of family firms handed down for generations. We describe and discuss the different impacts of tangible and intangible sources of tradition on the development of family SMEs. There is a gap in the literature about family firm's innovation issue. The results are inconsistent. We use a case study to investigate which variables affect innovation approach and how traditions can contribute to the development of new products or unique services.
\end{abstract}

Keywords: family business, innovation, family firm traditions, made in Italy, value creation

\section{Introduction}

Family firms represent an important organization for all the economies in the world (La Porta, Lopez-de-Silanes, Shleifer \& Vishny, 1999; Botero, Cruz, Massis, \& Nordqvist, 2015). The interaction between the family, the firm and each member of the family creates a unique entity different from another, with own values, rules, and human resources (Zahra, Hayton, \& Salvato, 2004; Habbershon, Williams, \& MacMillan, 2003). This interaction generates advantages and disadvantages in several financial, economic and social issue.

On innovation issue, several researches on family business have produced different results. Some researches explain that family business are conservative and less innovative than other firms but some statistics show that family businesses control more than $50 \%$ of European's most innovative firms . Others authors try to explain if there is a distinctive difference on innovation process among family firms and nonfamily firms (De Massis, Frattini, Pizzurno, \& Cassia 2013).

Some scholars say family businesses have risk aversion and their traditions do not encourage technological innovation (Levinson, 1991). Instead we believe that traditions can be a competitive factor.

Some researchers show an ever increasing importance of looking at the past as a source of innovation (Capaldo \& Petruzzelli, 2014; Presenza, Messeni Petruzzelli, \& Sheehan, 2019), as this can allow the discovery of values, practices and skills that can contribute to the development of new products or unique services. Therefore, a successful innovation could come from traditions mixed with new technologies. Consequently, new products / services could derive from the process of recombination of the tradition of some long-standing small family businesses and the adoption of cutting-edge technologies (Messeni Petruzzelli, \& Savino, 2015).

This vision of the process of innovation, defined as "recombinant perspective", states that "the creation of any kind of novelty in art, science or practical life consists - in substantial measure - of a recombination of previously existing conceptual and physical materials "(Nelson \& Winter 1982, p. 130; Savino, Messeni Petruzzelli and Albino, 2017). The aim of our research is to show with a qualitative analysis, that a family company through the traditions handed down to the future generations creates a greater competitive value because it generates unique products or services linked to the family tradition. With a case study and the help of an in-depth questionnaire we try to show innovative strategies by reinterpreting traditional resources.

\section{Literature Review}

Innovation represents the crucial base to increase competitiveness for business development (Schumpeter, 1934). According to Drucker (1985), innovation is the tool of entrepreneurs by which they exploit change as an opportunity. Innovation can concern either a new product or service or a new production system (Porter, 1990). The former is a question of technological or product innovation and in the latter concerns a new organizational 
process or a new managerial system (Crossan \& Apaydin, 2010). Innovation issue is not particularly investigated, in family firms. Results are not homogeneous and uniform. Scholars have found inconsistent results (Craig \& Moores 2006). It is not clear if there is a different propensity to innovation, and which is the variable that generates this different approach in family businesses. Some scholar finds that the family involvement in management roles affects how many resources are used (Sirmon \& Hitt, 2003). Thus is not clear, if family firm uses more or less resources for innovation and if the family involvement can change the inclination to innovate.

For this reason, qualitative analysis is still more relevant since investigates in a deep manner the phenomenon. This paper attempts to investigate the connection innovation-family traditions. We use as a case study a long-standing family firm at the fourth generation. The study attempts to analyse the innovation approach across generation. How the family firms' traditions affect the innovation approach? How the recombination of the traditions can create new products or services? How this relation create more values for the family firm's stakeholders?

The first empirical studies find that family firms consider innovation less relevant than non-family firms (Donckels \& Fröhlich, 1991). Dunn in 1996 observes that family firms are less pioneers in innovation. Stoy Hayward's study on 1992 showed that the propensity to innovation decreased as the family firm was transferred across generations. In other hand, for some scholars, "Familiness" affects sources of resistance to change, (Handler \& Kram, 1988) and in specific, Dunn (1996) explained the possibility that the commitment to maintain high the family reputation could stimulate to create excellent and quality products.

Levinson (1991) find that family firms have aversion to risk and their traditions did not encourage to the technological innovation. Westhead (1997) found a contradictory result; he showed that family firms had a competitive advantage in comparison with nonfamily firms because they offered innovation products and services.

Recent researches are also inconsistent. Craig and Dibrell (2006) find that family firms are more innovative than nonfamily firms. In contradiction, Chen and Hsu show that family businesses have a lower level of innovation process than nonfamily firm; Munoz-Bullon and Sanchez-Bueno (2011) find that family firms have a lower resources dedicated to Research and Development.

Thus some scholar propose a new kind of investigation. Cassia, De Massis and Pizzurno (2011) attempt to investigate how and why the innovation process is different among family firms and nonfamily firms proposing a set of family-related enabling and constraining factors for product innovation.

Miller, Wright, Le Breton-Miller (2015) and Scholes explain how the socioemotional wealth goals of family affect the level of innovation, creating a framework with 4 different approach to the innovation. De Massis, Di Minin, and Frattini attempt to explain the heterogeneity of innovation decisions into family firms.

These different results explain that the innovation issue needs to be more explored. Those three paper help to clarify that family firms have different behaviours and ambitions and different approach to innovation process. It is necessary a deep investigation and a quality analysis can help to emerge factors useful for next researches.

\section{Research Question and Methodology}

We use a case study, because we believe it is appropriate methodology when investigating a complex phenomenon that evolves over time, and also has many variables (Yin, 1995; Eisenhardt, 1989).

The case study allows to explore processes and allows us to consider different methods of data collection (Van Maanen, 1983). With the application of the so-called "triangulation" of the sources, it will be possible to explain better the phenomenon investigated. Although the case study can not generate statistical information, we can obtain a "analytical generalization" of the phenomenon studied (Yin, 1995). The qualitative analysis with the support of a case study, is still more relevant for understand which variables to observe and how and why family firms have different approach to innovation.

We analyse a family business in food sector, in Abruzzo region, specifically in pasta sector. It is a long-standing firm at the fourth generation. We believe that a firm existing for a long time can better explain the relation innovation-tradition in family business. In addition, it can better explain if family firm traditions can affect the innovation approach and how change the innovation process across generation. Verrigni is considered one of the excellence of made in Italy. It can explain how the family has maintain this success for more than 100 years, using more or less resources for innovation. How they compete on the market and with is their competitive advantage con creating value in the community.

The Family has a traditional production system passed down through generation, at the same time the new generation is oriented to the innovation looking the satisfaction of customers.

This study attempts to explore with a deep interview: 
1. How the family firms' traditions affect the innovation approach;

2. How the recombination of the traditions can create new products or services;

3. How this relation create more values for the family firm's stakeholders.

We used different sources: direct interviews to the family, a survey, literature review, archives, observation of the company's life, web site, etc. (Eisenhardt, 1989).

We used a structured questionnaire splits into 4 different issue:

- Governance;

- Innovation;

- Tradition;

- Value creating and competitiveness;

After we had an interview with the family and the management for achieve more deeply information about the family wishes, the reputation, the relation innovation and the family tradition.

\subsection{Verrigni Case Study: A Brief Story}

Verrigni is an Italian family business focused in the production and commercialization of pasta as shows the table 1. The firm is born in 1898, when Luigi Verrigni became supplier of the noble families of Rosburgo (now Roseto degli Abruzzi) that appreciated the superior quality of Verrigni pasta derived from the grinding of the finest wheats with stone millstones, mixed with the water of the Gran Sasso and dried by air suspended on bamboo reeds.

The corporate reputation of Verrigni pasta started to spread in the other Italian Regions and motivated Luigi's son (Gaetano) to introduce the innovative method of dessication through the use of "camerini" (little pasta drying rooms), ideal for pasta production. The same passion is conserved, with Gaetano Verrigni, the last generation. He is dedicated together Francesca Petrei Castelli, continuing the tradition involved in selecting the best hard wheats, using the traditional methods to production, including the dessication inside the "camerini" where pasta drying at slowly constant temperature (between - $45-50^{\circ}$ degrees) for as long as three days. The results are the unmistakable taste, one of the most important element of the corporate reputation linked to brand Verrigni Family, this is the highest quality of pasta.

Many of the most celebrated chefs in Italy (Massimiliano Alajmo, Massimo Bottura, Mauro Uliassi, Niko Romito, Moreno Cedroni) appreciate Verrigni thanks to the selection of the finest grain and bran and its use of old methods, coming from the tradition. "This appreciation of our products by Italy's leading chefs is indeed gratifying. It motivates us to maintain the high quality of our pasta. We have produced a line of pasta using the organic Abruzzo wheats reached by the property of Francesca Petrei Castelli in her small Agricolture farming located between Roseto degli Abruzzi and Pineto. In effect, Verrigni was one of the first Italian firms to produce pasta from organic wheats certified by Icea (the Ethical and Environmental Certificate Institute). Moreover, it has established its position in the organic pasta market thanks to its consistent high quality recognized by the distributors and consumers alike.

A huge innovation, in these last decades, was the "gold die" an important method introduced by Gaetano and the artist Sandro Seccia, conferring to pasta a very different consistency respect those grown by bronze die.

The Verrigni production consists in around 80 types of pasta, from the traditional to the modern. Many are available with brands of hard kamut wheat, Cappelli grain and farro. There is also a line of spicy pasta made with red pepper, spinach, octopus ink, saffron and many others. Research and innovation are constantly improved in Verrigni: day by day, to ensure quality, healthiness and environmental attention. At the same time, big attention for Made in Italy. 
Table 1. Verrigni, four generation

\begin{tabular}{ll}
\hline Founded & 1898 \\
\hline Founder & Luigi Verrigni \\
Annual Turnover & $€ 2.000 .000$ \\
Employees & $7: 3$ packaging; 1 warehouse sales management; 2 administration; 1 Quality manager. (consulting 3 times at \\
& week) \\
Generation of $\quad$ family & Fourth generation \\
control & \\
Values & Tradition, Innovation, Quality. \\
Recognitions & IFS (higher grade), Demeter. \\
Production & Around 80 types of pasta, from traditional to modern types of pasta design \\
\hline
\end{tabular}

Source: Our elaboration.

\section{Discussion}

In this section, the findings of the case study are used to illustrate the connection tradition-innovation in family firm. We used a structured questionnaire and an interview to the family members for a deep analysis.

For four generation Verrigni produced pasta bounded to the traditional methods, respecting absolutely the made in Italy of raw materials and the strictest quality assurances.

The following table shows what are the most important item to improve value creation in this Business Family.

Table 2. Items for value creation at verrigni

\begin{tabular}{ll}
\hline VALUE CREATION STEP & VALUE CREATION FACTORS \\
\hline FAMILY ITEMS & - Name of the Family (brand) \\
& - Ownership Control \\
& - Family Commitment \\
FAMILY BUSINESS ITEMS & - Quality of product \\
& - Innovation \\
& - organization; \\
& - process; \\
& - product \\
\hline
\end{tabular}

Source: Our elaboration.

\subsection{Family Items}

\subsubsection{Name/Reputation}

The Family Businesses are indissolubly tied to the history: the last generation Gaetano, after 4 generation continues to observing the same methods of its ancestors, translated one century of experience in this sector to the future generation yet. Over the decades, the Family followed the male primogeniture principle for leather succession. Thus, in the case of first child was a female, the successor was the second, etc. In case of lack of expertise in the first son, he was replaced by the second.

Certainly, the name of the Family has reputed fondant, then the choice to remain with the same name, despite the change of the family business in the 2007.

\subsection{Ownership Control}

Over the years, the family firm has lost a lot in terms of family heritage due to various negligence in the company's management. Therefore, in 2007, the family decided to sell the existing company and to create a new company, with the same name: Verrigni. The new company is divided into Gaetano Verrigni, last successor of family, and Francesca Petrei Castelli, the first wife of Gaetano. Other non-family figures are employed with a discretional decisional power: all the choices are allowed by the supervision of Francesca or Gaetano who will confirm actions in order to improve the success of the Family firm. 


\subsection{Family Commitment}

Family belief and values, the long experience in pasta production are the guide action that will lead to successful innovation.

\subsection{Knowledge, skills, ability}

Knowledge is the most important requirement to every person involved in Verrigni Family Business. The choice of new staff, the quotidian decisions, the choice referred to new investments, etc., all family business activities requires elements like as knowledge, experience and above all skills to reduce the risks to wrong decision. If there are not the base of these elements it is necessary to find methods, training, or other to improve them. But this not enough for family or nonfamily members: it is necessary

It is not enough for non-family members to have the prerequisite knowledge, skills, and abilities, it is necessary they must believe in those skills, feeling they are able to accomplish specific role and if they aren't able, they must obtain with training, studies, experience, or through a consultant, etc. This is a very important phase in this moment of restarting. Furthermore, for innovation efficacy, self-appraisal regarding one's ability to succeed becomes a critical readiness factor.

Also, self-efficacy has accounted for differences in coping mechanisms, stress reactions, and goal achievement (Daspit \& Holt 2015).

\subsection{Family Business Items}

\subsubsection{Quality of Product}

For the family, quality means use of an excellent raw material (finest wheats combined with the water of Gran Sasso) and method of production that exalts this excellence (stone millstones and drying in bamboo reeds or the use of "camerini", little pasta drying rooms at low temperature for more than one day). If a wrong production method is used, such as drying at too high temperatures, the raw material loses its excellent qualities.

\subsubsection{Innovation}

Innovation requires firms to acquire new or reconfigure existing competencies (Henederson and Clark, 1990), overcome organizational inertia (Tusman and O-Reilly III, 1996) and reform the top management team (Tusman and O-Reilly III, 2004).

\subsubsection{Innovation of the Organization}

Verrigni Family Business has different phases in the last decade. Starting from 2008, it is coined the new company: limited Company "Antico Pastificio Rosetano". It maintain the name Verrigni for the product pasta. Gaetano Verrigni with Francesca Petrei Castelli start the new era. There are the new employed in the organization of the company and in the future it will have new entry (i.e. an export manager). In this new organization the mission is "ensure quality by the knowledge form the past (tradition) and the contribute of new ideas and new activities (innovation). In this way, innovation is the need create surprise effect with something new without detriment Quality.

Until before 2007 there was a flattened management with direct only for private labels ... the Verrigni brand was nearly unknown, except for very few packs and moreover with a very different meaning logo respect to the actual brand born in the 2008. The first important change was the interruption of private labels. Starting from 2008, the pasta product sell out on the market with the Verrigni brand. What is the results? Although, revenues rose slightly, the important result is the knowledge of Verrigni brand and his history, his value, his quality. Then, the results in terms of the net profitability are different to the past profitability with the production regard to private label. The future activities was focused to the knowledge and the awareness around the meaning of Verrigni brand.

The market is continuously rising and there are need many activities and initiatives to know the brand Verrigni products.

\subsection{Innovation Process}

In addition to the innovative processes introduced by the past generations (including i.e. organic production), new production processes have been introduced in the last decade. The first and most important change was the introduction of the "gold die". Verrigni is the only one pasta producer with this precious method to confer different consistency than i.e. bronze molds. A remarkable value as well as a competitive advantage.

In the field of organic Verrigni obtained the IFS certification with the highest grade: Higher Grade. 
In 2009 Verrigni obtained the DEMETER certification (Demeter is the brand for products from Biodynamic Agriculture, and only a strictly controlled and contractually bound partner is allowed to use the Brand. Applicable organic regulations in the various countries, without any gap, from the agricultural production to the processing and final product packaging).

In 2010 he can participates for the first time in Nuremberg at the Biofach: the first official experience in the biodynamic world.

Furthermore, Verrigni also has an Official Quality System (which integrates and supports HACCP regulations).

\subsection{Innovation Product}

Observations, insights, studies and focus on all product already offered and what are the lack. Ideas coming from the creativity and the knowledge of Gaetano's reflections, in addition to Francesca's ideas not only for pasta. The result of Gaetano's ideas with experience of family experience, the know-how and expertise in terms of new market opportunities.

The innovations are particularly focused on the pasta product, not only:

1. new formats (more than 80 different types), among them are the "aromatized lines ", prepared with natural flavours and the egg-pasta;

2. new line "VV", born in 2011 thanks to a collaboration with Francesco Paolo and Elena Valentini of the Valentini wine Family Business, one of the oldest and most prestigious in Abruzzo. "Made in Abruzzo" and "gold die" for some packs, using grain of San Carlo, a precious wheat;

3. Biological line (ICEA certified);

4. Biodynamic line (DEMETER certified);

5. "spaghetto al volo", born from the idea of Francesca, to obtain at the same time high quality prepared in a few minutes: a very interesting innovation both consumers and restaurants;

6. rice, born in collaboration with the Cooperative Ecorì cooperative in Vercelli (the most important place in terms of rice producers in Italy), $100 \%$ made in Italy of the highest quality;

7. Extra virgin olive oil, obtained by the Francesca Petrei Castelli farm: this is one of the product $100 \%$ made in Abruzzo;

8. tomatoes sauce, beans and chickpeas (beans "tondino del Tavo" and "cece nano" typically legumes of the Abruzzo territory) born from the collaboration with the Fabio Belfiore Farm in Abruzzo, thus $100 \%$ made in Abruzzo;

9. "Piattine di riso", rice breadstick, obtained by the collaboration with TD firm, in Vercelli, $100 \%$ made in Italy;

10. Beers thanks to the collaboration with the Almond Company, one of the most famous brewer, leader in Abruzzo above all in Italy in the production of beer, are born two different flavors: "birrolo" with pink spelled and grapefruit and "Sa. Fr. An.", a special saffron beer, 100\% made in Abruzzo, really high quality;

11. Saffron, honey and saffron butter, produced thanks to the collaboration with Croco and Similace firm, around Pisa, $100 \%$ made in Italy;

12. "Zero Zero Oro" fragrance, in collaboration with perfumers masters PRO FVMVM ROMA;

13. new lines of kitchen aprons and shopping bags (little small market offering).

\subsection{Made in Italy}

It is an important item of a mission in Verrigni. Gaetano and Francesca will continue to offer product made in Italy, combined with made in Abruzzo above all, or with preference on the South Italy, a very rich territory of natural resources.

One of the most important question was: "Can you satisfy the production quantity with the made in Italy fin terms of wheat, particularly?" The answer was "Absolutely!".

It's not quantity problem, but fair price. In Italy there are a lot of wheat growers, above all in the South Italy, who do not exist, they stopped their activities, after the competition on prices referred to wheat coming from abroad. If the growers were adequately remunerated, the grain would have its own market and the Italian pasta could be $100 \%$ made in Italy. In the last few years the real challenge is to spread a culture of healthy: the meaning is not linked with saving. On the other side, it is not correct propose a price off-market. Pasta in Italy represents the every-day 
dish, and consumer are not able to spend an excessively. If every of this point are correct there will be a right revenue for everybody: consumer with health; producers and growers with correct revenue.

\section{Conclusions}

Verrigni is characterized by a strong combination of tradition and innovation in terms of organization, process and product. One of their mission is an uninterrupted innovation process. They use many resources of the firm in research and development. The innovation approach is became stronger with the last generation. They think that survive in fast changing of the market is necessary to innovate, move up costumers tastes, and at the same time maintain big quality. The family has relevant traditions in the production system, hand down from generations. Family Traditions do not limit the orientation to innovation.

According to Francesca and Gaetano (the owners), innovation and tradition are not opposites, on the contrary, a blend of the two topics, has been crucial in order to start new organization, to achieve new value added, maintaining a sustainable competitive advantage, improving corporate reputation.

Tradition and innovation, we can say too: "Continuity and change". Two apparently contradictory and irreconcilable keywords, but they create the correct balance and harmony for a family business growing its longevity and its competitive advantage.

In this optical view, it is possible to combine government styles, results to different generations with their individual stories, their aspirations, attitudes, and ambitions.

Thus, Verrigni with this combination: tradition-innovation is able to obtain:

- Longevity source of competitive advantage;

- Acquisition and development of skills and abilities thanks to the experience;

- Ability to revamp and reposition the brand Verrigni in the market;

- Change, as a critical phase to manage, an important opportunity for analysis of itself;

- Coherence with the past and future development planning;

- Exploring new ways to adapt in changing market needs;

One of the most important examples of successful innovation through the tradition of the Verrigni family is that it has used traditional grandparent recipes improved by emerging chefs for recipes in a short time to meet women in career.

They also made a type of pasta that is cooked in seconds, responding to the time and needs of customers with little time, keeping the Italian tradition with its organoleptic characteristics. That is, they dried the pasta at low temperature, pierced in gold, maintaining the typical and fresh flavours of the grandmother's pasta.

The traditions of Italian cuisine through technological innovation have allowed the consumer to grow the sensation of cooking authentic and fresh flavours even with innovative products.

Family businesses should focus on their traditions and improve them by obtaining unique products and increasing the value generated for their customers and other stakeholders.

\section{Contribution of Research}

This case study offers a new perspective to investigate the relationship between family business tradition and innovation, value creation, made in Italy. The findings suggest a new pathway and encourage the discussion on the topic.

\section{References}

Barron, D. N., West, E., \& Hannan, M. T. (1994). A time to grow and a time to die: growth and mortality of credit unions in New York City, 1914-1990. American Journal of Sociology, 100(2), 381-421.

Botero, I. C., Cruz, C. D., De Massis, A., \& Nordqvist, M. (2015). Family Business Research in the European Context. European Journal of International Management, 9(2), 139-159.

Capaldo, A., \& Petruzzelli, A. M. (2014). Partner geographic and organizational proximity and the innovative performance of knowledge-creating alliances. European Management Review, 11(1), 63-84. https://doi.org/abs/10.1111/emre.12024

Capaldo, A., Lavie, D., \& Messeni Petruzzelli, A. (2017). Knowledge Maturity and the Scientific Value of Innovations: The Roles of Knowledge Distance and Adoption. Journal of Management, 43(2), 503-533.https://doi.org/10.1177/0149206314535442 
Carr, J. C., \& Ring, J. K. (2017). Family Firm Knowledge Integration and Noneconomic Value Creation. Journal of Managerial Issue, 14(1), 30-56.

Cassia, L., De Massis, A., \& Pizzurno, A. (2012). Strategic innovation and new product development in family firms: An empirically grounded theoretical framework. International Journal of Entrepreneurial Behaviour \& Research, 18(2), 198-232. https://doi.org/10.1108/13552551211204229

Craig, J. B. L., \& Dibrell, C. (2006). The natural environment, innovation and firm performance: a comparative study. Family Business Review, 19(4), 275-288. https://doi.org/10.1111/j.1741-6248.2006.00075.x

Craig, J. B. L., \& Moores, K. (2006). A 10-year longitudinal investigation of strategy, systems, and environment on innovation in family firms. Family Business Review, 19(1), 1-10. https://doi.org/10.1111/j.1741-6248.2006.00056.x

Craig, J. B., Dibrell, C., \& Garrett, R. (2014). Examining relationships among family influence, family culture, flexible planning systems, innovativeness and firm performance. Journal of Family Business Strategy, 5(3), 229-238. http://dx.doi.org/10.1016/j.jfbs.2013.09.002

Crossan, M. M., \& Apaydin, M. (2010). A multi-dimensional frame work of organizational innovation: a systematic review of the literature. Journal of Management Studies, 47, 1154-1191. https://doi.org/10.1111/j.1467-6486.2009.00880.x

Daspit, J. J., \& Holt, D. T. (2015). Diagnosing Innovation Readiness in Family Firms. California Management Review, 58(1), 82-96. https://doi.org/10.1525/cmr.2015.58.1.82

De Massis, A., Frattini, F., \& Lichtenthaler, U. (2013). Research on technological innovation in family firms: present debates and future directions. Family Business Review, 26(1), 10-31. https://doi.org/10.1177/0894486512466258

De Massis, A., Frattini, F., Pizzurno A., \& Cassia, L. (2013). Product innovation in family versus non family firms: an exploratory analysis. Journal of Small Business Management, 53(1), 1-36. https://doi.org/10.1111/jsbm.12068

Debicki, B. J., Van de Graaf, R., \& Sobczak, M. (2017). Socioemotional Wealth and Family Firm Performance: a Stakeholder Approach. Strategic Issue in the Family Firm, 29(1), 82-111.

Donckels, R., \& Fröhlich, E. (1991). Are family businesses really different? Family Business Review, 4(2), 149-60. https://doi.org/10.1111/j.1741-6248.1991.00149.x

Drucker, P. (1985). Innovation and entrepreneurship. New York, NY: Harper \& Row.

Dunn, B. (1996). Family enterprises in the UK: a special sector? Family Business Review, 9(2), 139-55. https://doi.org/10.1111/j.1741-6248.1996.00139.x

Habbershon, T. G., Williams, M., \& MacMillan, I. C. (2003). A unified systems perspective of family firm performance. Journal of Business Venturing, 18(4), 451-65. https://doi.org/10.1016/S0883-9026(03)00053-3

Handler, W. C., \& Kram, K. E. (1988). Succession in family firms: the problem of resistance. Family Business Review, 1(4), 361-81. https://doi.org/10.1111/j.1741-6248.1988.00361.x

Hatak, I., Kautonen, T., Fink, M., \& Kansikas, J. (2016). Innovativeness and family-firm performance: the moderating effect of family commitment. Technological Forecasting and Social Change, 102, 120-131. https://doi.org/10.1016/j.techfore.2015.02.020

Henderson, R. M., \& Clark, K. B. (1990). Architectural innovation: the reconfiguration of existing product technologies and the failure of established firms. Administrative Science Quarterly, 35(1), 9-30.

Katila, R. (2002). New product search over time, past ideas in their prime? Academy of Management Journal, 45(5), 995-1010. https://doi.org/10.5465/3069326

Kotlar, J., Fang, H., De Massis, A., \& Frattini, F. (2014). Profitability goals, control goals, and the R\&D investment decisions of family and nonfamily firms. Journal of Product Innovation Management, 31(6), 1128-1145. https://doi.org/10.1111/jpim.12165

La Porta, R., Lopez-de-Silanes, F., Shleifer, A., \& Vishny, R. (1999). Corporate Ownership around the World. Journal of Finance, 54(2), 471-517. https://doi.org/10.1111/0022-1082.00115

Leonard-Barton, D. (1992). Core capabilities and core rigidities: A paradox in managing new product development. Strategic Management Journal, 12(S1), 111-125. https://doi.org/10.1002/smj.4250131009 
Levinson, R. E. (1991). Problems in managing a family-owned business. In C. E. Aronoff \& J. L. Ward (Eds.), Family business sourcebook (pp. 169-174). Detroit: Omnigraphics.

Marler, L., Botero, I., \& De Massis, A. (2017). Succession-Related Role Transitions in Family Firms: The Impact of Proactive Personality. Journal of Managerial Issue, 29(1), 57-81.

Miller, D., Wright, M., Le Breton-Miller, I., \& Scholes, L. (2015). Resources and innovation in family businesses : the Janus-face of family socioemotional preferences. California management review, 58(1), 20-40. http://dx.doi.org/10.1525/cmr.2015.58.1.20

Munoz-Bullon, F., \& Sanchez-Bueno, M. J. (2011). The impact of family involvement on the R\&D intensity of Publicly traded firms. Family Business Review, 24(19), 62-70. https://doi.org/10.1177/0894486510396870.

Nelson, R. R., \& Winter, S. G. (1982). The Schumpeterian trade off revisited. The American Economic Review, 72(1), 114-132.

O’Reilly, C. A., \& Tushman, M. L. (2004). The ambidextrous organization, Harvard Business Review, 82(4), 74-81.

Porter, M. (1990). The competitive advantage of nations. London, England: Mcmillan.

Presenza, A., Messeni Petruzzelli, A., \& Sheehan, L. (2019), "Innovation trough tradition in hospitality. The Italian case of Albergo Diffuso. Tourism Management, 72, $192-201$. https://doi.org/10.1016/j.tourman.2018.11.020

Savino, T., Messeni, P. A., \& Albino, V. (2017). Search and recombination process to innovate: A review of the empirical evidence and a research agenda. International Journal of Management Reviews, 19(1), 54-75. https://doi.org/abs/10.1111/ijmr.12081

Schumpeter, J. (1934). The Theory of economic development. Cambridge, MA: Harvard University Press.

Sirmon, D. G., \& Hitt, M. A. (2003). Managing resources: linking unique resources, management, and wealth creation in family firms. Entrepreneurship Theory and Practice, 27(4), 339-58. https://doi.org/10.1111/1540-8520.t01-1-00013

Sorensen, J. B., \& Stuart, T. B. (2000). Aging, obsolescence, and organizational innovation. Administrative Science Quarterly, 45(1), 81-112. https://doi.org/10.2307/2666980

Stoy Hayward/BBC. (1992). Family Business Index. London: Stoy Hayward.

Teece, D. J. (2014). The foundations of enterprise performance: dynamic and ordinary capabilities in an (economic) theory of firms. Academy of Management Perspectives, 28(4), 328-352. https://doi.org/10.5465/amp.2013.0116

Westhead, P. (1997). Ambitions, external environment and strategic factor differences between family and nonfamily companies. Entrepreneurship \& Regional Development, 9(2), 127-158. https://doi.org/10.1080/08985629700000007

Zahra, S. A., \& Sharma, P. (2004). Family Business Research: A Strategic Reflection. Family Business Review, 17(4), 331-346. https://doi.org/10.1111/j.1741-6248.2004.00022.x

Zahra, S. A., Hayton, J. C., \& Salvato, C. (2004). Entrepreneurship in family vs non-family firms: a resource-based analysis of the effect of organizational culture. Entrepreneurship Theory and Practice, 28(4), 363-81. https://doi.org/10.1111/j.1540-6520.2004.00051.x

\section{Copyrights}

Copyright for this article is retained by the author(s), with first publication rights granted to the journal.

This is an open-access article distributed under the terms and conditions of the Creative Commons Attribution license (http://creativecommons.org/licenses/by/4.0/). 